\title{
Studies on the Metabolism of Mould Fungi
}

\section{PHOSPHORUS METABOLISM IN MOULDS}

\author{
Bx T. MANN (Nenior Beit Memorial Fellow), Molteno Institute, University of Cambridge
}

(Received 22 May 1944)

Phosphorus, together with nitrogen, sulphur, mag. nesium and organically bound carbon, has been one of the few elements long recognized as indispensable for the growth and metabolic activities of the mould fungi (Lafar, 1904). Much later other elements, such as iron, copper, zinc, manganese, molybdenum and gallium, were added to the list of essential nutrients (Foster, 1939). It has been repeatedly shown that many moulds, including numerous species of Asper. gillus, Penicillium and Rhizopus, are unable to grow unless small amounts of phosphate are present in the nutrient medium.

The first systematic study of the phosphorus metabolism in moulds was carried out by Vorbrodt $(1920,1926,1928)$, who demonstrated that growing mycelia of Aspergillus niger take up orthophosphate from the culture media and store it partly in the inorganic form and partly in the form of new compounds. More recently, Michel-Durant (1938) observed that the uptake of orthophosphate by $A$. niger is insignificant at the early stage of mycelial growth but that it assumes bigger proportions at the stage of the formation of the conidia. According to this author, there are three groups of phosphorus compounds in the mycelium, a small 'lipoid fraction' and two ethanol-insoluble fractions, one of which is soluble in trichloroacetic acid ('phosphore organique soluble indéterminé') and the other acid-insoluble, represented by the non-extractable residue.

The paucity of data concerning the chemical nature of the phosphorus compounds in moulds and their metabolic function is in striking contrast to the wealth of information available regarding phosphorus compounds in yeast, bacteria, higher plants and animal tissues. It seemed, therefore, desirable to investigate the nature and behaviour of phosphorus compounds in moulds, and to examine the possibility of the existence in moulds of a link between the phosphorus metabolism and other processes, such as the metabolism of carbohydrate. (Preliminary communication, Mann, 1943.)

\section{EXPERIMENTAL}

The stock cultures used for inoculation were grown on beerwort-agar slopes and were subcultured once a month. The majority of the experiments was carried out with A. niger v. Tiegh. (National Collection of Type Cultures (N.C.T.C.) no. 594), but occesionally other moulds were used, such as $A$. niger citricus Neuberg (N.C.T.C. no. 1692), A. niger Thaysen (N.C.T.C. no. 603), Penicillium oxalicum Currie-Thom (N.C.T.C. no. 983) and $P$. notatum Westling-Fleming (N.C.T.C. no. 4222). The culture media were composed of $10 \%$ glucose, $0.5 \%$ $\mathrm{NaNO}_{3}, 0.1 \% \mathrm{MgSO}_{4} .7 \mathrm{H}_{2} \mathrm{O}$, with varying amounts of $\mathrm{K}_{2} \mathrm{HPO}_{4}$, dissolved in tap water. $50-300 \mathrm{ml}$. portions of the medium were used and distributed in crystallizing dishes to a depth not exceeding $1.5 \mathrm{~cm}$. The inoculum amounted to approximately $1 \mathrm{mg}$. of spore material (dry wt.) per $100 \mathrm{ml}$. medium. The mycelia were usually grown at $30^{\circ}$ under aseptic conditions.

The disappearance of glucose from the medinm of the growing culture was followed quantitatively by the method of Benedict. The total amount of organic acids produced and excreted by the mycelium into the medium was asseseed by titration with $0.1 \mathrm{~N}-\mathrm{NaOH}$ in presence of phenolphthalein as indicator. Owing to the presence of gluconic acid in lactone form, a rather long time was required to reach the end-point of titration. Besides gluconic acid, the two other main organic acids produced were citric acid and oxalic acid. Citric acid was determined gravimetrically as pentabromoacetone and oxalic acid as calcium oxalate.

Before performing any phosphorus analysis of the mycelium, the medium was siphoned from beneath the mycelium and replaced by the same volume of water. Care was taken not to submerge any part of the surface of the mycelium. After two more changes of water at $8 \mathrm{hr}$. intervals, the mycelium was spread evenly on a glass plate and quickly divided with a sharp knife into several parts. Some of the material was used for the estimation of the dry weight (at $105^{\circ}$ ) and for the determination of the total content of phosphorus, and the remainder was thoroughly extracted with cold trichloroacetic acid. This extract, which contained the total acid-soluble phosphorus; was used for the estimation of: (1) the true inorganic phosphorus determined as $\mathrm{MgNH}_{4} \mathrm{PO}_{4} ;$ (2) phosphorus determined as phosphate which reacts directly with ammonium molybdate, $\mathbf{P}_{0}$; (3) the phosphorus which appears as orthophosphate after 7 and 30 min. hydrolysis with N-HCl, $P_{7}$ and $P_{30}$; (4) phosphorus as the total phosphate after incineration with $\mathrm{H}_{2} \mathrm{SO}_{4}$ and $\mathrm{HNO}_{3}, \mathrm{P}_{\text {tot. }}$ (Lohmann \& Jendrassik, 1926).

Nitrogen was estimated by the Kjeldahl procedure. The assays for nicotinic acid, riboflavin and aneurin were very kindly undertaken by Dr E. Kodičk and Dr Y. L. Wang of the Nutritional Laboratory, Cambridge. 
Growth and metabolism of Aspergillus niger in presence of varying concentrations of phosphate

With $0.002 \% \mathrm{~K}_{2} \mathrm{HPO}_{4}$ or less in the culture medium no growth or only a very poor growth of $A$. niger was observed and conidia appeared very late, if at all. With $0.02 \% \mathrm{~K}_{2} \mathrm{HPO}_{4}$, thin mycelia appeared 2 days after sowing and developed within the next 2 days into strong, white, smooth pellicles. Usually on the 4th day of growth the first black conidiophores made their appearance. With 0.2-

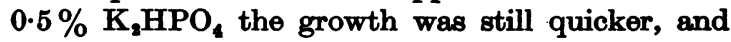
within 4 days a very thick mycelium was produced which, instead of being white and smooth, showed a creased surface and was of a distinctly yellowish colour, especially at the surface in contact with the medium. No conidiophores were present at that stage. They usually appeared on the 6th or 7th day of growth.

Both the rate at which phosphate was absorbed from the medium as well as the concentration which it finally reached in the mycelium were found to depend on the initial amount of $\mathrm{K}_{2} \mathrm{HPO}_{4}$ in the medium. With $0.02 \% \mathrm{~K}_{2} \mathrm{HPO}_{4}$ in the medium, the rate of disappearance was so rapid that after 3 days of growth the medium was completely depleted of phosphorus; the final concentration of phosphorus reached in the mycelium was about $0.3 \% P$ (dry wt.). With $0.2-0.5 \% \mathrm{~K}_{2} \mathrm{HPO}_{4}$ in the medium, the rate of absorption of phosphate by the growing mycelium was somewhat slower during the first days of growth and reached a higher level only at the preconidial stage; the final concentration of phosphorus in the mycelium was 1-2 \% P (dry wt.).

Effect of phosphate concentration on metabolism. By varying the concentration of phosphate in the medium it was possible to influence markedly both the carbohydrate and the nitrogen metabolism of the mould, as well as its respiration. Table 1 illustrates the differences between two cultures, $A$ and B, grown in the presence of 0.02 and $0.2 \% \mathrm{~K}_{2} \mathrm{HPO}_{4}$, respectively. The culture $B$ grew faster than the culture $A$; it utilized glucose more rapidly and turned a higher proportion of it into citric acid. In addition, it was capable of building up a much larger store of nitrogen than the phosphorus-deficient culture $A$. The nitrogen stored in the mycelium, derived from the nitrate of the medium, was found to be entirely of organic nature; neither nitrate nor free ammonia could be detected. Approximately one-half of the mycelium- $N$ could be extracted with trichloroacetic acid or with other deproteinizing reagents. Among the N-containing substances thus extracted were aneurin, riboflavin and nicotinic acid. It is of considerable interest to note that in response to an increased concentration of inorganic phosphate in the medium, the formation of all three vitamins was enhanced to such an extent as to compare favourably with rich vitamin sources such as liver or yeast. The high riboflavin content is responsible for the yellow colour of the phosphorusrich mycelium, and also, it may have some bearing on the fact that such a mycelium, when separated from its medium and transferred to water, continued to respire for several days much more vigorously

Table 1. Effect of varying concentration of orthophosphate on the metabolism of A. niger

A

grown in presence of $0.02 \% \mathrm{~K}_{2} \mathrm{HPO}_{4}$

Mycelium (5 days old)

Appearance

Dry weight

$\mathrm{Q}_{\mathrm{O}_{2}}$ of intact mycelium

$Q_{\mathrm{O}_{2}}$ of mycelium pulp

$Q_{\mathrm{O}_{2}}$ of pulp $+1 \%$ glucose

Total nitrogen, mg.

Total phosphorus, mg.

Magnesium, mg.

Aneurin, $\mu \mathrm{g}$.

Riboflavin, $\mu \mathrm{g}$.

Nicotinic acid, $\mu \mathrm{g}$.

Medium (50 ml.)

Appearance

Glucose, $\%$

Glucose oxidase activity; $2 \mathrm{ml}$. medium $+10 \mathrm{mg}$.

glucose, $\mathrm{pH} \mathrm{7,} 30^{\circ}$, take up in 15 min.

Total phosphorus, mg.

Titratable total acidity, ml. N-acid

Citric acid, ml. N-acid

Oxalic acid, ml. w-acid

\begin{tabular}{|c|c|}
\hline $\begin{array}{l}\text { Thin, white, smooth, } \\
\text { first conidiophores }\end{array}$ & $\begin{array}{l}\text { Thick, yellowish, no } \\
\text { conidiophores }\end{array}$ \\
\hline $\begin{array}{c}460 \mathrm{mg} . \\
6 \cdot 2 \\
0 \cdot 4 \\
30 \cdot 0\end{array}$ & $\begin{array}{c}1092 \mathrm{mg} . \\
11.4 \\
1.9 \\
19.0\end{array}$ \\
\hline $\begin{array}{r}8 \cdot 1 \\
1 \cdot 5 \\
3 \cdot 8 \\
3 \cdot 2 \\
16 \cdot 1 \\
19 \cdot 4\end{array}$ & $\begin{array}{r}23 \cdot 7 \\
12 \cdot 1 \\
6 \cdot 8 \\
19 \cdot 0 \\
78 \cdot 7 \\
302 \cdot 0\end{array}$ \\
\hline $\begin{array}{c}\text { Colourless } \\
3 \cdot 7 \\
120 \mu 1 . O_{2}\end{array}$ & $\begin{array}{l}\text { Yellow } \\
0 \cdot 1 \\
30 \mu \mathrm{l} . \mathrm{O}_{2}\end{array}$ \\
\hline $\begin{array}{c}0 \cdot 0 \\
15 \cdot 0 \\
3 \cdot 8 \\
0 \cdot 05\end{array}$ & $\begin{array}{r}6 \cdot 3 \\
16 \cdot 0 \\
7.9 \\
0.0\end{array}$ \\
\hline
\end{tabular}


then the P-deficient mycelium. Grinding of the mycelia with water caused a pronounced fall in the $\mathrm{O}_{2}$ uptake, but even then, the pulp obtained from the mycelium $\mathrm{B}$ had a much higher rate of $\mathrm{O}_{2}$ uptake than that prepared from mycelium A. When; however, glucose was added to the pulp, the $\mathrm{O}_{2}$ uptake increased more in $\mathbf{A}$ than in $\mathbf{B}$. This was due to a higher activity of glucose oxidase in the mycelium $A$.

\section{The absorption of phosphate from the medium and} the formation of phosphorus compounds in the mycelium

Absorption of phosphate. The experiments recorded in Table 2 were carried out with $A$. niger v. Tiegh. in crystallizing dishes containing $50 \mathrm{ml}$. of the medium described, with $0.2 \% \mathrm{~K}_{2} \mathrm{HPO}_{4}$ and grown at $30^{\circ}$. Thin mycelia usually appeared $24 \mathrm{hr}$. after sowing, and the production of gluconic and citric acid, at the expense of glucose, soon followed. At the same time, the absorption of phosphate from the medium began to be noticeable. Occasionally the rate of the absorption of phosphate by the growing mycelium was rather slow during the first days of growth and reached a higher velocity only at the preconidial stage. In other instances, however, the absorption proceeded rapidly from the beginning of the growth and was well marked at an early stage of growth, several days before the appearance of the first conidiophores.

Formation of phosphorus compounds in the mycelia. In order to follow the fate of the absorbed phosphate, a study was made of the content and the distribution of phosphorus compounds in the mycelia. A large proportion of the phosphorus which accumulated in the inycelia, sometimes as much as $90 \%$, could be extracted by grinding the mycelia thoroughly with trichloroacetic acid. Only a small proportion of the acid-soluble phosphorus, 10-20\% in all, behaved like ordinary orthophosphate, and the value of the phosphorus determined directly $\left(P_{0}\right)$ equalled that in the magnesium-ammonium-phosphate precipitate. A large proportion of the total acid-soluble phosphorus, as assessed by incineration with $\mathrm{H}_{2} \mathrm{SO}_{4}$ and $\mathrm{HNO}_{3}$, broke down completely to orthophosphate after a $7 \mathrm{~min}$. hydrolysis with $1 \mathrm{~N}-\mathrm{HCl}$ at $100^{\circ}$, and thus behaved like a typical 'easily acid-hydrolyzable phosphorus compound'. Only a small proportion of the phosphorus present in the mycelium was found to occur in a 'difficultly hydrolyzable' form.

The formation of the phosphorus compounds in the mycelium usually reached its peak at the time when the first conidiophores were appearing. At the same time the medium was already depleted of $50-90 \%$ of the orthophosphate originally present, as well as of glucose, and contained large quantities of gluconic acid and citric acid. When the concentration of these two acids had reached its maximum, oxalic acid was still absent, and could be found only later, after the mycelium had lived for several days at the expense of the first two organic acids. As soon as the reserve of gluconic and citric acid was exhausted, the process of autolysis set in, heralded by a decrease in the dry weight of the mycelium and accompanied by a rapid decomposition of the phosphorus compounds in the mycelium and the reappearance of orthophosphate in the medium.

\section{Table 2. Phosphorus metabolism in growing cultures of A. niger}

$\left(P_{0}=\right.$ phosphorus determined as phosphate which reacts directly with ammonium molybdate; $P_{7}=$ the phosphorus which appears as orthophosphate after $7 \mathrm{~min}$. hydrolysis with $\mathrm{N}-\mathrm{HCl} ; \mathrm{P}_{30}=$ the phosphorus which appears as orthophosphate after $30 \mathrm{~min}$. hydrolysis with $\mathrm{N}-\mathrm{HCl} ; \mathrm{P}_{\text {tot. }}=$ phosphorus as the total phosphate after incineration with $\mathrm{H}_{2} \mathrm{SO}_{4}$ and $\mathrm{HNO}_{3}$.)

\begin{tabular}{|c|c|c|c|c|c|c|c|c|c|c|c|c|c|}
\hline & \multicolumn{6}{|c|}{ Mycelium } & \multicolumn{6}{|c|}{ Medium (50 ml.) } \\
\hline & & \multirow{3}{*}{ Appearance } & \multirow{2}{*}{$\begin{array}{l}\text { Dry } \\
\text { wt. } \\
\text { (g.) }\end{array}$} & \multicolumn{4}{|c|}{$\begin{array}{c}\text { Trichloroacetic acid extracts } \\
\text { mg. P }\end{array}$} & \multirow{2}{*}{$\begin{array}{l}\text { Glu. } \\
\text { cose } \\
\text { (g.) }\end{array}$} & \multirow{2}{*}{$\begin{array}{l}\text { Total } \\
\text { acidity } \\
\text { (ml. N- } \\
\text { acid) }\end{array}$} & \multirow{2}{*}{$\underset{\text { (mg.) }}{\mathbf{P}_{\mathbf{0}}}$} & \multirow{2}{*}{$\begin{array}{l}P_{\text {tot. }} \\
\text { (mg.) }\end{array}$} & \multirow{2}{*}{$\begin{array}{l}\text { Citric } \\
\text { acid } \\
\text { (ml. N- } \\
\text { acid) }\end{array}$} & \multirow{2}{*}{$\begin{array}{l}\text { Oxalic } \\
\text { acid } \\
\text { (ml. N- } \\
\text { acid) }\end{array}$} \\
\hline & & & & $\mathbf{P}_{0}$ & $P_{7}$ & $P_{80}$ & $P_{\text {tot. }}$ & & & & & & \\
\hline & 0 & & - & - & 一 & 一 & - & $\mathbf{5 \cdot 0}$ & 0.0 & $17 \cdot 8$ & $17 \cdot 8$ & - & - \\
\hline I & $\begin{array}{r}2 \\
3 \\
5 \\
9 \\
14\end{array}$ & $\begin{array}{l}\text { Thin, continuous } \\
\text { White, strong } \\
\text { First conidia } \\
\text { Many conidia } \\
\text { Autolysis }\end{array}$ & $\begin{array}{l}0.506 \\
1.056 \\
1.340 \\
1.728 \\
0.932\end{array}$ & $\begin{array}{l}0 \cdot 4 \\
1 \cdot 5 \\
1 \cdot 5 \\
1 \cdot 1 \\
2 \cdot 6\end{array}$ & $\begin{array}{r}1 \cdot 6 \\
5 \cdot 0 \\
9 \cdot 0 \\
\cdot 12 \cdot 3 \\
4 \cdot 8\end{array}$ & $\begin{array}{r}\overline{5 \cdot 5} \\
9 \cdot 5 \\
12 \cdot 9 \\
-\end{array}$ & $\begin{array}{r}\overline{6 \cdot 5} \\
11 \cdot 0 \\
14 \cdot 0 \\
-\end{array}$ & $\begin{array}{l}- \\
1 \cdot 1 \\
0 \cdot 1 \\
0 \cdot 0 \\
0 \cdot 0\end{array}$ & $\begin{array}{r}3 \cdot 2 \\
15 \cdot 0 \\
18 \cdot 0 \\
5 \cdot 5 \\
0 \cdot 3\end{array}$ & $\begin{array}{r}\overline{10 \cdot 5} \\
5 \cdot 0 \\
0 \cdot 0 \\
8 \cdot 0\end{array}$ & $\begin{array}{r}\overline{10 \cdot 5} \\
5 \cdot 0 \\
0 \cdot 0 \\
9 \cdot 6\end{array}$ & $\begin{array}{l}0 \cdot 6 \\
3 \cdot 9 \\
6 \cdot 9 \\
5 \cdot 5 \\
0 \cdot 0\end{array}$ & $\begin{array}{l}0 \cdot 0 \\
0 \cdot 0 \\
0 \cdot 0 \\
0 \cdot 1 \\
0 \cdot 3\end{array}$ \\
\hline II & $\begin{array}{r}2 \\
4 \\
6 \\
14\end{array}$ & $\begin{array}{l}\text { Thin, continuous } \\
\text { White, strong } \\
\text { Few conidia } \\
\text { Autolysis }\end{array}$ & $\begin{array}{l}0.352 \\
0.760 \\
1.356 \\
0.816\end{array}$ & $\begin{array}{l}0 \cdot 2 \\
0 \cdot 7 \\
2 \cdot 3 \\
\mathbf{4} \cdot 6\end{array}$ & $\begin{array}{l}1 \cdot 5 \\
5 \cdot 7 \\
9 \cdot 0 \\
6 \cdot 3\end{array}$ & $\begin{array}{r}1 \cdot 5 \\
6 \cdot 1 \\
10 \cdot 3 \\
6 \cdot 3\end{array}$ & $\begin{array}{r}1 \cdot 8 \\
10 \cdot 0 \\
12 \cdot 0 \\
6 \cdot 8\end{array}$ & $\begin{array}{l}1 \cdot 1 \\
0 \cdot 3 \\
0 \cdot 0 \\
0 \cdot 0\end{array}$ & $\begin{array}{r}6 \cdot 5 \\
12 \cdot 5 \\
7 \cdot 5 \\
0 \cdot 0\end{array}$ & $\begin{array}{l}16 \cdot 0 \\
0 \cdot 0 \\
6 \cdot 0\end{array}$ & $\begin{array}{l}16 \cdot 0 \\
0 \cdot 0 \\
6 \cdot 0\end{array}$ & - & - \\
\hline III & $\begin{array}{r}3 \\
5 \\
8 \\
12 \\
19\end{array}$ & $\begin{array}{l}\text { White, strong } \\
\text { First conidia } \\
\text { Many conidia } \\
\text { Onset of autolysis } \\
\text { Autolysis }\end{array}$ & $\begin{array}{l}0.320 \\
0.792 \\
1.150 \\
0.920 \\
0.510\end{array}$ & $\begin{array}{l}1 \cdot 5 \\
0 \cdot 7 \\
0 \cdot 6 \\
- \\
-\end{array}$ & $\begin{array}{r}5 \cdot 0 \\
8 \cdot 6 \\
10 \cdot 0 \\
- \\
-\end{array}$ & $\frac{-}{-}$ & $\begin{array}{c}\overline{-} \\
\overline{12 \cdot 0} \\
-\end{array}$ & $\begin{array}{l}1 \cdot 1 \\
0.0 \\
0.0 \\
0.0 \\
0.0\end{array}$ & $\begin{array}{r}13.0 \\
15.5 \\
8.0 \\
2.0 \\
0.0\end{array}$ & $\begin{array}{r}- \\
0.0 \\
0.3 \\
11.0\end{array}$ & $\begin{array}{r}- \\
\overline{0.0} \\
0.5 \\
12.0\end{array}$ & $\begin{array}{l}4.0 \\
4.6 \\
5.0 \\
1.0 \\
0.0\end{array}$ & $\begin{array}{c}0.0 \\
0 \cdot 0 \\
0.0 \\
1 \cdot 0 \\
\text { Trace }\end{array}$ \\
\hline
\end{tabular}


Table 3. Formation of an easily acid-hydrolyzable phosphorus compound in moulds

\begin{tabular}{|c|c|c|c|c|c|c|}
\hline \multirow[b]{3}{*}{ Species } & \multicolumn{3}{|c|}{ Mycelium } & & & \\
\hline & \multirow[b]{2}{*}{$\begin{array}{l}\text { Dry wt. } \\
\text { (g.) }\end{array}$} & \multicolumn{2}{|c|}{$\begin{array}{c}\text { Trichloroacetic acid } \\
\text { extracts (mg. P) }\end{array}$} & \multicolumn{3}{|c|}{ Medium (50 ml.) } \\
\hline & & $* P_{0}$ & $* P_{7}$ & $\begin{array}{c}\text { Glucose } \\
\text { (g.) }\end{array}$ & $\begin{array}{c}\text { Acidity } \\
\text { (ml. } \text { N-acid) }\end{array}$ & $\begin{array}{l}* \mathbf{P}_{0} \\
\text { (mg.) }\end{array}$ \\
\hline $\begin{array}{l}\text { A. niger v. Tiegh. } \\
\text { A. niger citricus Neuberg } \\
\text { A. niger Thaysen } \\
P \text {. oxalicum } \\
P \text {. notatum }\end{array}$ & $\begin{array}{l}1 \cdot 196 \\
1 \cdot 008 \\
1 \cdot 252 \\
0 \cdot 624 \\
0.960\end{array}$ & $\begin{array}{l}2 \cdot 7 \\
0 \cdot 6 \\
5 \cdot 3 \\
0 \cdot 2 \\
1 \cdot 3\end{array}$ & $\begin{array}{l}\mathbf{9 \cdot 4} \\
1 \cdot 3 \\
\mathbf{6} \cdot \mathbf{6} \\
\mathbf{3} \cdot 0 \\
\mathbf{4 \cdot 7}\end{array}$ & $\begin{array}{c}0.0 \\
0.8 \\
0.0 \\
\mathbf{3 ; 3} \\
\text { Trace }\end{array}$ & $\begin{array}{c}9 \cdot 5 \\
11 \cdot 5 \\
1 \cdot 5 \\
0 \cdot 75 \\
10 \cdot 5\end{array}$ & $\begin{array}{r}2 \cdot 5 \\
12 \cdot 5 \\
2 \cdot 5 \\
10 \cdot 0 \\
10 \cdot 0\end{array}$ \\
\hline
\end{tabular}

The formation of easily hydrolyzable phosphorus from orthophosphate is not restricted to one strain of $A$. niger but was found also with other moulds (Table 3). However, the amounts of the readily hydrolyzable phosphorus formed by these moulds were smaller than with $A$. niger v. Tiegh.

Effect of oxygen and respiratory inhibitors on phos. phorus metabolism. The absorption of phosphate from the medium and the formation of phosphorus compounds in the mycelium were found to depend strictly on the presence of oxygen. In this respect the phosphorus metabolism of moulds differs substantially from the various phosphorylation processes which occur in yeast and in animal tissues. Cyanide and azide $(0.001 \mathrm{~N})$, iodoacetate $(0.001 \mathrm{~N})$ and fluoride $(0.005 \mathrm{~N})$ were found to have a powerful inhibitory effect on the respiration as well as on the carbohydrate metabolism of the moulds; at the same time these inhibitors strongly suppressed the phosphorus metabolism.

The effect of these inhibitors could best be studied on mycelia grown directly in the cups of Barcroft differential manometers (Table 4).

A. niger was sown on $5 \mathrm{ml}$. medium. During the early stages of growth the shaking of the manometers had to be avoided owing to the great fragility of the fresh mycelium. With a continuous mycelium gentle shaking could be safely applied, but it had little effect on the extent of the oxygen consumption owing to the fact that the mycelium respires mainly on the surface. After 4 days of growth at $30^{\circ}$ the manometer cups containing the pellicles were attached to the manometers and the course of the respiration was followed quantitatively. The oxygen uptake of the mycelia was measured at $30^{\circ}$, and expressed in terms of

$$
Q_{\mathrm{O}_{2}}=\frac{\mu \mathrm{l} . \mathrm{O}_{\mathrm{g}} \text { taken up }}{\mathrm{mg} . \text { dry wt. } \times \mathrm{hr} \text {. }}
$$

On the addition of inhibitors the absorption of phosphate from the medium came suddenly to a standstill. The action of the inhibitors on the respiration and the phosphate absorption could be reversed provided the mycelium had not been left in contact with the poison for more than a few hours. Otherwise an autolysis set in and the phosphorus compounds formed in the mycelium broke down rapidly with the liberation of free phosphate.

In order to demonstrate the effect of oxygen on the phosphate metabolism it was found convenient to grow mycelia for several days on media deficient in phosphate $\left(0.01-0.02 \%\right.$ instead of $\left.0.2 \% \mathrm{~K}_{2} \mathrm{HPO}_{4}\right)$, but otherwise composed as described above. If these mycelia were then transferred to $0.1 \% \mathrm{KH}_{2} \mathrm{PO}_{4}$ in

Table 4. Effect of respiratory inhibitors on the phosphorus metabolism

Mycelium grown on $5 \mathrm{ml}$. medium in Barcroft manometer cups; 4 days at $30^{\circ}$.

\begin{tabular}{|c|c|c|c|c|c|c|c|c|}
\hline \multicolumn{2}{|c|}{ Addition to the medium } & \multirow{2}{*}{$\begin{array}{l}\text { Analyzed } \\
\text { after } \\
\text { (hr.) }\end{array}$} & \multicolumn{4}{|c|}{ Mycelium } & \multicolumn{2}{|c|}{ Medium } \\
\hline Substance & $\begin{array}{c}\text { Concentration } \\
\text { (M) }\end{array}$ & & $\begin{array}{c}\text { Dry wt. } \\
\text { (mg.) }\end{array}$ & $Q_{O_{2}}$ & $\begin{array}{l}{ }^{*} P_{0} \\
\text { (mg.) }\end{array}$ & $\begin{array}{l}{ }^{*} P_{7} \\
\text { (mg.) }\end{array}$ & $\begin{array}{l}* P_{0} \\
\text { (mg.) }\end{array}$ & $\begin{array}{l}{ }^{*} P_{7} \\
\text { (mg.) }\end{array}$ \\
\hline - & - & 一 & 90 & $12 \cdot 7$ & 0.07 & 0.60 & 0.08 & 0.08 \\
\hline Iodoacetate & $\begin{array}{l}0.001 \\
0.001\end{array}$ & $\begin{array}{r}3 \\
\mathbf{2 4}\end{array}$ & $\begin{array}{l}90 \\
82\end{array}$ & $\begin{array}{l}3 \cdot 6 \\
1 \cdot 6\end{array}$ & $\begin{array}{l}0.09 \\
0.09\end{array}$ & $\begin{array}{l}0.60 \\
0.40\end{array}$ & $\begin{array}{l}0.09 \\
0.30\end{array}$ & $\begin{array}{l}0.09 \\
0.32\end{array}$ \\
\hline Fluoride & $\begin{array}{l}0.005 \\
0.005 \\
0.01 \\
0.01 \\
0.02 \\
0.02\end{array}$ & $\begin{array}{r}3 \\
24 \\
3 \\
\mathbf{2 4} \\
\mathbf{3} \\
\mathbf{2 4}\end{array}$ & $\frac{\overline{80}}{\frac{80}{60}}$ & $\begin{array}{l}5 \cdot 8 \\
2 \cdot 3 \\
4 \cdot 8 \\
1 \cdot 9 \\
1 \cdot 3 \\
0.5\end{array}$ & $\begin{array}{l}\overline{0} \\
0.09 \\
\overline{0.05} \\
\overline{0.05}\end{array}$ & $\begin{array}{l}\overline{-40} \\
\overline{0.40} \\
\overline{0.40}\end{array}$ & $\begin{array}{l}\overline{0.10} \\
\overline{0.20} \\
\overline{0.20}\end{array}$ & $\begin{array}{l}\overline{0.10} \\
\overline{0.25} \\
\overline{0.25}\end{array}$ \\
\hline Azide & $\begin{array}{l}0.001 \\
0.001\end{array}$ & $\begin{array}{r}3 \\
24\end{array}$ & $\overline{65}$ & $\begin{array}{l}2 \cdot 8 \\
1 \cdot 3\end{array}$ & $\begin{array}{l}0.07 \\
0.09\end{array}$ & $\begin{array}{l}0.50 \\
0.40\end{array}$ & $\begin{array}{l}0 \cdot 10 \\
0 \cdot 30\end{array}$ & $\begin{array}{l}0.10 \\
0.32\end{array}$ \\
\hline Cyanide & 0.001 & 3 & 90 & 1.5 & 0.08 & 0.55 & 0.10 & 0.10 \\
\hline
\end{tabular}

* See note to Table 2. 
the presence of oxygen, they quickly utilized the inorganic phosphate and built up from it the easily hydrolyzable phosphorus compound (Fig. 1, curve I). Anaerobically, there was no change in the content of $\mathrm{KH}_{2} \mathrm{PO}_{4}$ in the medium (Fig. 1, curve II). When, 'after a period of anaerobic incubation, oxygen was let in, the mycelium responded immediately with renewed absorption of phosphate. However, the absorption never reached the same level as with mycelia which had not been exposed to anaerobic conditions. The reason is that even a short period of anaerobiosis has a general adverse effect on the

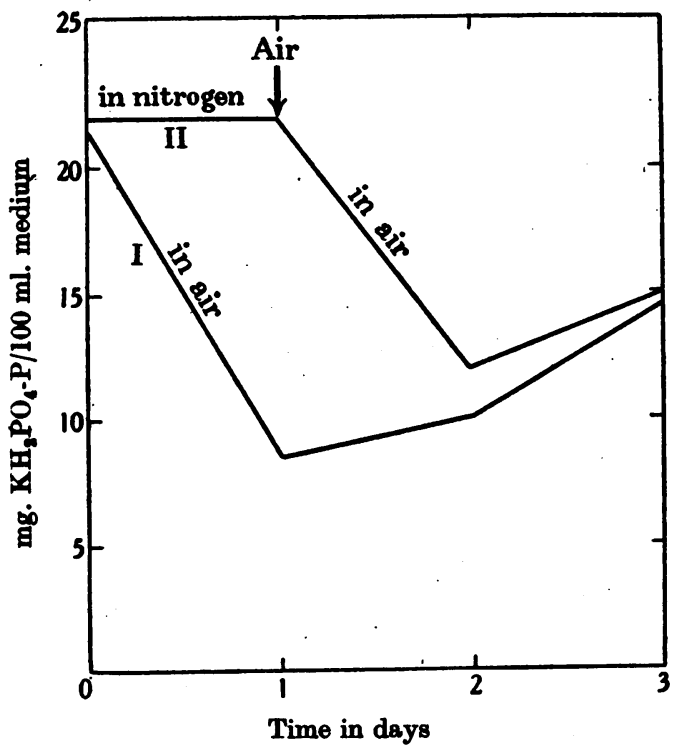

Fig. 1. The absorption of phosphate from the medium in presence and absence of oxygen

metabolic activities of the mycelium. A prolonged lack of oxygen was found to lead invariably to autolysis.

When mycelia were transferred to neutralized solutions of sodium pyrophosphate or of certain sugar-phosphoric acid esters instead of to orthophosphate, the process of phosphate absorption was slower because it was preceded by the breakdown of the phosphoric compounds into orthophosphate (Table 5). Glucose had a slightly delaying effect on the process of phosphate absorption.

\section{Metaphosphatase}

It is essential to use trichloroacetic acid for the successful extraction of phosphorus compounds from the mycelium. When the mycelium was ground with water instead of with trichloroacetic acid, the acidhydrolyzable phosphorus compounds of the pulp broke down within a short time to orthophosphate. They could be preserved, however, either by heating the pulp to $100^{\circ}$ and keeping it at this temperature for a few minutes or by rapidly dehydrating the pulp with acetone and converting to a dry powder. No losses in the acid-soluble phosphorus occurred during the acetone treatment which, however, did remove all acetone-soluble substances including some acetone-soluble, difficultly hydrolyzable phosphoris compound. The distribution of phosphorus, nitrogen and magnesium, between the acetone extract, the acetone powder and the trichloroacetic acid extract from the acetone powder of one mycelium, is illustrated by the scheme shown on p. 344 .

The assumption that the breakdown of phosphorus compounds in the mycelium ground with water might be due to the presence of a phosphatase was strengthened by the observation that if such a pulp was brought into contact with a variety of phosphoric acid derivatives, it decomposed them quickly into orthophosphate.

The phosphatase contained in the mycelium could be extracted with water without any loss of activity. The extract (1 ml.; $12 \mathrm{mg}$. dry wt.), when acting upon $2 \mathrm{ml}$. substrate ( $\mathrm{Na}$ salts; $1.2 \mathrm{mg}$. P) for $3 \mathrm{hr}$. at $\mathrm{pH} 5$ and $30^{\circ}$, converted to orthophosphate $70-98 \%$ of the following compounds: pyrophosphate, metaphosphate, hexametaphosphate, $\alpha$-phosphoglycerol, $\beta$-phosphoglycerol, Cori ester (1-phosphoglucose), Embden ester (6-phospho-hexose),

\section{Table 5. Metabolism of pyrophosphate and sugar-phosphoric acid esters by the mycelium}

\begin{abstract}
Mycelium grown in manometer vessel. On the fifth day medium replaced by $5 \mathrm{ml}$. of:

Water
\end{abstract}

Sodium pyrophosphate (4 mg. P)

$\mathrm{K}$ salt of Cori ester (6 mg. P)

Na. salt of Embden ester (6 mg. P)

\begin{tabular}{|c|c|}
\hline $\begin{array}{c}\text { Incubation } \\
\text { at } 30^{\circ} \\
\left(\mathbf{h r}_{\mathbf{.}}\right)\end{array}$ & $\begin{array}{c}Q_{\mathrm{O}_{2}} \text { of } \\
\text { mycelium }\end{array}$ \\
\hline $\begin{array}{r}0 \\
16\end{array}$ & $\begin{array}{l}8 \cdot 3 \\
6 \cdot 3\end{array}$ \\
\hline $\begin{array}{r}0 \\
16\end{array}$ & $\begin{array}{r}9 \cdot 2 \\
10 \cdot 0\end{array}$ \\
\hline $\begin{array}{r}0 \\
16\end{array}$ & $\begin{array}{r}9 \cdot 4 \\
12 \cdot 8\end{array}$ \\
\hline $\begin{array}{r}0 \\
16\end{array}$ & $\begin{array}{r}8 \cdot 6 \\
11 \cdot 9\end{array}$ \\
\hline
\end{tabular}

* See note to Table 2.

\begin{tabular}{|c|c|c|}
\hline \multicolumn{3}{|c|}{ Media } \\
\hline $\begin{array}{l}{ }^{* P_{0}} \\
\text { (mg.) }\end{array}$ & $\begin{array}{l}{ }^{*} P_{q} \\
\text { (mg.) }\end{array}$ & $\underset{\text { (ml. N-acid) }}{\text { Acidity }}$ \\
\hline $\begin{array}{l}0.0 \\
0.05\end{array}$ & $\begin{array}{l}0.0 \\
0.05\end{array}$ & $\begin{array}{l}0.0 \\
0.25\end{array}$ \\
\hline $\begin{array}{l}0.0 \\
2 \cdot 5\end{array}$ & $\begin{array}{l}4 \cdot 0 \\
3 \cdot 0\end{array}$ & $\begin{array}{l}0 \cdot 0 \\
0 \cdot 14\end{array}$ \\
\hline $\begin{array}{l}0.0 \\
3.9\end{array}$ & $\begin{array}{l}6.0 \\
4.5\end{array}$ & $\begin{array}{l}0.0 \\
0.16\end{array}$ \\
\hline $\begin{array}{l}0.0 \\
2.5\end{array}$ & $\begin{array}{l}0.1 \\
2 \cdot 5\end{array}$ & $\begin{array}{l}0.0 \\
0.08\end{array}$ \\
\hline
\end{tabular}




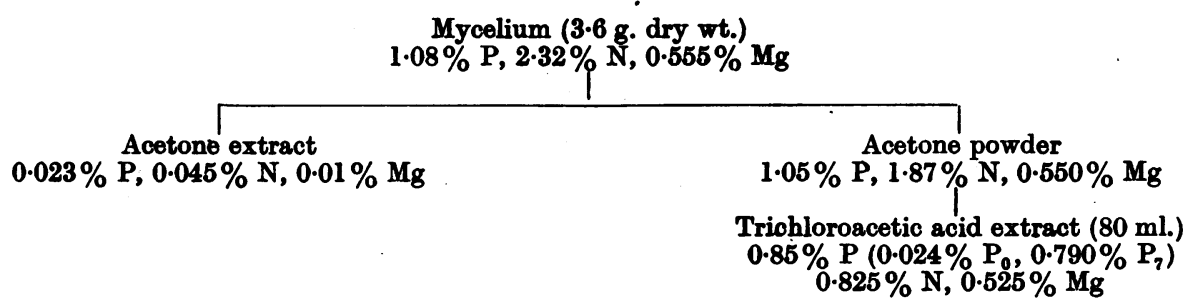

Harden-Young ester (1:6-diphospho-fructose), 3phosphoglycerate, adenosine triphosphate (all three atoms of phosphorus), muscle adenylate, yeast adenylate, aneurin diphosphate and phytate.

The outstanding property of this polyphosphetase, and one which sets it apart from other known phosphatases, is the ease with which it acted on metaphosphate. This enzyme may therefore be referred to as a metaphosphatase.

The only instance. where metaphosphatase activity has been previously described in moulds is the observation made by Kitasato $(1928 a, b)$,' who found that preparations of 'Taka-phosphatase' from $A$. oryzae are active towards metaphosphate. He had to use, however, as much as $1 \mathrm{~g}$. of Takaphosphatase and incubate this preparation for $20 \mathrm{hr}$. with $250 \mathrm{mg}$. sodium metaphosphate in order to obtain $10 \%$ of the phosphorus in the form of orthophosphate. Compared with the metaphosphatase of $A$. niger the activity of 'Taka-phosphatase' appears to be negligible.

Metaphosphatase in metabolism fluid. The examination of the culture media separated from the mycelia of $A$. niger revealed that they too possessed considerable metaphosphatase activity; $2 \mathrm{ml}$. medium separated from a 4-day-old mycelium and incubated for $5 \mathrm{hr}$. with $2 \mathrm{ml}$. sodium metaphosphate ( $0.6 \mathrm{mg}$. P) converted it completely to orthophosphate. Incidentally, the presence of the phosphatase in the medium provides an explanation for the observation that organic phosphorus compounds added to the culture media are first dephosphorylated and then absorbed as orthophosphate.

Purification of metaphosphatase. In order to purify the metaphosphatase and 'to obtain the enzyme free from glucose oxidase (always present alike in the mycelium and the medium), the aqueous extracts from the mycelia were dialyzed, the enzyme was precipitated with 3 vol. of cold acetone, redissolved in water and finally purified by adsorption on tricalcium phosphate gel and alumina $\mathrm{C}_{\gamma}$. In this manner it was possible to obtain metaphosphatase preparations practically free from glucose oxidase. In addition, it was found that 0.01 M-sodium nitrate had a strong inhibitory effect on the activity of glucose oxidase at $\mathrm{pH} 5$ (but not at $\mathrm{pH} 7$ ), whereas it did not affect the activity of metaphosphatase at all. The optimum activity of metaphosphatase oc. curred at $\mathrm{pH} 3 \cdot 7-4 \cdot 2$. A purified enzyme preparation $(60 \mu \mathrm{g}$.) incubated with a solution of sodium metaphosphate or pyrophosphate $(0.3 \mathrm{mg}$. P) for $2 \mathrm{hr}$. at $\mathrm{pH} 5$ and $30^{\circ}$ converted both compounds quantitatively to orthophosphate.

\section{DISCUSSION}

Unlike the animal tissues and yeast cells, the metabolic activities of the mould fungi, especially those of the acid-producing species like Aspergillus and Penicillium, depend to a large extent on the presence of oxygen. Aspergillus niger, for instance, will oxidize sugar very efficiently in the presence of oxygen to non-volatile organic acids such as gluconic, citric and oxalic acid, whereas anaerobically it scarcely ferments sugar at all. This phenomenon was well known to the early investigators, and Duclaux in his Traite de Microbiologie (1898) very appropriately referred to the process of oxalic acid formation in moulds as 'respiration oxalique', a term which is more suitable than the later 'oxalic fermentation' or 'oxidative fermentation'. The experiments described in this paper demonstrate for the first time that in addition to the carbohydrate metabolism, the phosphorus metabolism of $A$. niger is also strictly aerobic in character. In this respect the moulds differ again from yeast, where the presence or absence of oxygen is said to be of little importance so far as the absorption of phosphate is concerned (Mullins, 1942). The intimate relationship between the phosphorus metabolism and the respiration of $A$. niger is best demonstrated by the fact that various inhibitors of mould respiration, such as cyanide, azide, iodoacetate and fluoride, also stop phosphorus metabolism. This fact indicates a connexion between the metabolism of carbohydrate and that of phosphorus compounds in moulds. Moreover, an increase in the content of phosphate in the culture medium enhances both the utilization of carbohydrate and the formation of organic acids, particularly citric acid. However, the increased production of citric acid may also be due to changes in the nitrogen metabolism.

Mycelia grown in the presence of high phosphate concentrations have a much higher nitrogen metabolism than those grown on phosphate-deficient media and are capable of building up a considerable reserve of various valuable nitrogenous substances. 
Another point which emerged is that the mycelia of various moulds convert a large proportion of the absorbed orthophosphate into acid-hydrolyzable phosphorus compounds. One of these compounds breaks down completely to orthophosphate after a 7 min. hydrolysis with $\mathrm{N}-\mathrm{HCl}$ at $100^{\circ}$, and thus behaves like pyrophosphate. Another compound occurs in the 'difficultly hydrolyzable' fraction.

It is interesting to note that $A$. niger, which contains an abundant store of phosphorus compounds in the mycelium, also possesses a highly active phosphatase. This enzyme acts optimally under the acid conditions prevailing in the mould culture. It attacks a variety of derivatives of phosphoric acid, among them metaphosphate, a fact which will be commented upon in the next paper of this series.

\section{SUMMARY}

1. Mould fungi with a predominantly aerobic carbohydrate metabolism have also a characteristic aerobic phosphorus metabolism. They absorb orthophosphate aerobically and convert it into a number of phosphorus compounds.

2. The rate with which phosphate is absorbed and utilized depends on its initial concentration in the culture medium. Cultures grown in the presence of large concentrations of phosphate develop more rapidly than those grown in low concentrations, have a higher respiratory quotient, utilize glucose more rapidly, produce more citric acid, have a higher nitrogen metabolism and exhibit a substantially increased content of certain vitamins.

3. Cyanide and azide $\left(0.001:^{-}\right)$, iodoacetate $(0.001 \mathrm{~N})$ and fluoride $(0.005 \mathrm{~N})$ strongly inhibit the respiration of these moulds, and bring the phosphorus metabolism to a standstill.

4. A large proportion of the orthophosphate absorbed aerobically is converted to acid-hydrolyzable compounds. One of these compounds breaks down to orthophosphate after a $7 \mathrm{~min}$. hydrolysis with $\mathrm{N}-\mathrm{HCl}$, and thus behaves like a typical 'easily hydrolyzable phosphorus compound'. Another compound occurs in a 'difficultly hydrolyzable' form.

5. The formation of phosphorus compounds in the mycelium reaches its peak at the preconidial stage. During autolysis these compounds are decomposed and excreted into the medium as orthophosphate.

6. The occurrence of a metaphosphatase in both the mycelium and the culture medium of Aspergillus niger is described. The enzyme has been purified and separated from glucose oxidase. Whereas the activity of glucose oxidase is considerably reduced by $0.01 \mathrm{~N}-\mathrm{NaNO}_{3}$, the phosphatase activity remains intact.

\title{
REFERENCES
}

Duclaux, E. (1898). Traité de Microbiologie. Paris: Masson. Foster, J. W. (1939). Bot. Rev. 5, 207.

Kitasato, T. (1928a). Biochem. Z. 197, 257.

(1928b). Biochem. Z. 201, 206.

Lafar, F. (1904). Handbuch der technologischen Mykologie. Jena: Fischer.

Lohmann, K. \& Jendrassik, L. (1926). Biochem. Z.178, 419.
Mann, T. (1943). Nature: Lond., 151, 619.

Miohel-Durant, E. (1938). Bull. Soc. Chim. biol., Paris, 20, 399.

Mullins, L. J. (1942). Biol. Bull. Woods Hole, 88, 326.

Vorbrodt, W. (1920). Bull. int. Acad. Cracovie, 71. (1926). Bull. int. Acad. Cracovie, 517. (1928). Acta Biol. exp., Varsovie, 1, 5.

\section{Studies on the Metabolism of Mould Fungi}

\section{ISOLATION OF PYROPHOSPHATE AND METAPHOSPHATE FROM ASPERGILLUS NIGER}

\author{
By T. MANN (Senior Beit Memorial Fellow), Molteno Institute, University of Cambridge
}

(Received 22 May 1944)

The mycelium of Aspergillus niger contains a large proportion of its phosphorus in the form of compounds which can be easily extracted with trichloroacetic acid and which yield orthophosphoric acid after acid hydrolysis. In order to obtain more definite information with regard to the chemical nature of these compounds an attempt was made to isolate them from the mycelium.

\section{EXPERIMENTAL}

The first step in the purification procedure was the extraction of the mycelia with trichloroacetic acid. This was followed by precipitation with $\mathrm{Pb}\left(\mathrm{NO}_{3}\right)_{2}$, by means of which two distinct fractions were obtained which will be referred to as ' $\mathrm{Pb}$ fraction $\mathrm{I}$ ' and ' $\mathrm{Pb}$ fraction $I I$ '. The first fraction precipitated 